\title{
Electroporation-mediated genetic transformation of oil palm (Elaeis guineensis)
}

\author{
CHRIS DARMAWAN ${ }^{1, \bullet}$, NI MADE ARMINI WIENDI ${ }^{2}$, CONDRO UTOMO $^{1}$, TONY LIWANG ${ }^{1}$ \\ ${ }^{1}$ Biotechnology Department, Plant Production and Biotechnology Division. PT SMART Tbk. Jl. Cijayanti, Babakan Madang, Bogor 16810, West Java, \\ Indonesia. Tel./fax. +62-21-3925720, `email: biotechnology@ sinarmas-agri.com \\ ${ }^{2}$ Department of Agronomy and Horticulture, Faculty of Agriculture, Institut Pertanian Bogor. Jl. Meranti, Bogor 16680, West Java, Indonesia
}

Manuscript received: 10 June 2020. Revision accepted: 24 July 2020.

\begin{abstract}
Darmawan C, Wiendi NMA, Utomo C, Liwang T. 2020. Electroporation-mediated genetic transformation of oil palm (Elaeis guineensis). Biodiversitas 21: 3720-3726. Novel traits introduction to existing varieties may shorten the duration of oil palm genetic improvement. This approach heavily relies on efficient plant transformation and regeneration methods. Commonly used methods such as biolistic and Agrobacterium-mediated transformation still generated low efficiency for oil palm. Therefore, it is important to find alternative transformation methods that have the potency to give better results. Electroporation is usually used for delivering genes into bacteria or plant protoplast where cell wall does not exist, however, in this research, it was used to deliver plasmid into plant tissues. The aim of this research is to establish an optimum electroporation protocol for delivering genes into oil palm calli. Electric field strength of $250,500,750,1,000$, and 1,250 V/cm were applied for oil palm calli electroporation. Transient GUS assay was not applicable for initial detection presumably due to oil palm endogenous GUS-like protein activity after electroporation. Delivered gene could be detected in survived calli from all tested electric field strength treatments and the highest calli growth rates were observed from $250 \mathrm{~V} / \mathrm{cm}$ electroporation treatment. Overall results showed that electroporation could be used to deliver specific genes into oil palm calli and might be developed further to increase its efficiency.
\end{abstract}

Keywords: Electroporation, genetic engineering, oil palm, transformation

\section{INTRODUCTION}

Oil palm (Elaeis guineensis Jacq.) has been improved through breeding programs that focused on yield traits for several decades. Due to its nature as a perennial crop, oil palm conventional breeding is a long process that requires a large planting field and huge manpower. The integration of other useful traits such as disease resistance and drought tolerance to existing oil palm varieties will require a lot of effort and time due to the required number of crosses and backcrosses (Parveez et al. 2012). Given the fact that oil palm is a major source of vegetable oil for the world, another approach for genetic improvement is needed to accelerate its development.

Genetic engineering can be used to introduce novel genes to oil palm varieties and produce high-value traits that are almost impossible to be obtained through conventional breeding (Masani et al. 2018). This technique may shorten the duration of oil palm breeding because the genetic modification can be applied directly to existing superior oil palm varieties and do not require backcross processes. Biolistic, which was recently used to deliver the gene for polyhydroxybutyrate production (Parveez et al. 2015), is the commonly used method for oil palm genetic transformation together with Agrobacterium-mediated method. It was reported that transformation rate of Agrobacteriummediated method could reach $0.7 \%$, slightly lower than the rate of biolistic method which was 1-1.5\% (Izawati et al. 2012). A higher transformation rate was achieved by PEG mediated transfection $(4.76 \%)$ and DNA microinjection (14\%) into oil palm protoplast cells (Masani et al. 2014). Although several methods have been used for oil palm genetic engineering, common transformation methods like biolistic and Agrobacterium-mediated transformation still generated low efficiency. On the other hand, other potential transformation methods like electroporation had never been used for oil palm genetic engineering and may provide an alternative transformation method.

Electroporation is one of physical methods that can be used to deliver transgenes into the cells (Ochatt 2013; Rivera et al. 2012). The technique uses strong electric fields to temporarily permeabilize biological cells (Reberšek, 2017). The formation of transient pores in the cell membrane by brief electrical pulses allows the transport of molecules such as DNA, RNA, proteins, drugs, and dyes into the cell (Kumar et al. 2019). Although most applications of electroporation in plant research used protoplast as a target, several studies proved that the technique could also be used to deliver genes directly into plant tissues. D'Halluin et al. (1992) successfully transformed maize immature zygotic embryos and embryogenic type I calli using electroporation which resulted in mature transgenic plants with stable integration of neomycin phosphotransferase gene. Tissue electroporation was also applicable to other explant types such as mature embryos (Liu et al. 2010) and microspore (Brew-Appiah et al. 2013). In addition, some of those research confirmed a stable inheritance of transgene in the progenies. 
Several parameters should be adjusted to obtain optimum transformation efficiency and electric field strength is one of the main variables in electroporation processes (Ochatt 2013). Applied electric pulse that exceeds cell membrane threshold field strength will induce pore formation (Saunders et al. 1995). Optimal electric field strength is essential for efficient DNA delivery into a plant cell. Therefore, the optimization of this parameter is necessary for efficient transformation. In this research, a range of electric field strengths was tested to deliver plasmid into oil palm calli. The research aimed at establishing an efficient electroporationmediated transformation method for oil palm calli.

\section{MATERIALS AND METHODS}

\section{Materials}

Embryogenic callus code 398-20 was obtained from Tissue Culture Research Laboratory of PT SMART Tbk, Jawa Barat, Indonesia, and used as plant materials in this research. Calli clump with size of 1-2 mm was selected using sterile metal sieve and used as explants. Calli in all procedures were maintained in dark conditions at $28 \pm 2{ }^{\circ} \mathrm{C}$ without light in plant growth room. The composition of oil palm callus proliferation medium (EE medium) was as follows: Murashige \& Skoog Basal Salt Mixture (PhytoTech Labs, USA), 0.9\% agar, 5\% sucrose, and 3.5 g/L 1-Naphthalene acetic acid (NAA). Electroporation buffer (EPM buffer) consists of $5.96 \mathrm{~g} / \mathrm{L} \mathrm{KCl} ; 0.56 \mathrm{~g} / \mathrm{L}$ $\mathrm{CaCl}_{2} ; 2.38 \mathrm{~g} / \mathrm{L}$ HEPES; and $77.42 \mathrm{~g} / \mathrm{L}$ mannitol with $\mathrm{pH}$ adjusted to 7.2 (D'Halluin et al. 1992). Phosphate buffer

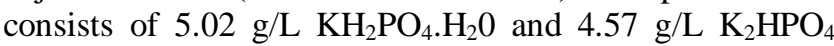
with $\mathrm{pH}$ adjusted to 7.0. Plasmid of pCAMBIA 1303 was used as transformation vector. It contains gusA-mgfp 5 fusion gene as reporter gene and hptII gene as selectable marker gene. The plasmid DNA was obtained from CAMBIA research organization in Australia. BTX ${ }^{\mathrm{TM}}$ Harvard Apparatus ECM ${ }^{\mathrm{TM}} 630$ Exponential Decay Wave Electroporator was used for electroporation processes and cuvettes with $0.4 \mathrm{~mm}$ gap between electrodes were used as electroporation containers.

\section{Methods}

Hygromycin lethal dose analysis

Hygromycin was used as selection agent and its optimal concentration for selection must be determined. Hygromycin lethal doses toward oil palm calli were observed by culturing selected oil palm calli in EE media supplemented with different concentrations of hygromycin at $0,5,10,15$, $20,25,30$, and $35 \mathrm{ppm}$, respectively. The percentage of dead calli in selection medium was observed at week 8 .

\section{Electric field strength optimization}

Calli were soaked in $500 \mathrm{uL}$ EPM buffer that contained $5 \mu \mathrm{g}$ pCAMBIA 1303 plasmid in $0.4 \mathrm{~mm}$ gap electroporation cuvettes. It was incubated for 1 hour at room temperature and 10 minutes in ice prior to electroporation. Electric field strengths of 0, 250, 500, 750, 1,000 , and $1,250 \mathrm{~V} / \mathrm{cm}$ were applied to calli with a $960 \mu \mathrm{F}$ capacitance and $50 \Omega$ resistances. Calli were further incubated in ice for 10 minutes before transferred to $\mathrm{EE}$ medium supplemented with $0.2 \%$ Plant Preservative Mixture/PPM (v/v) (Plant Cell Technology, USA). Transformed calli selections were started one month after electroporation. Electroporated calli were transferred to EE medium supplemented with $0.2 \%$ PPM and $15 \mathrm{ppm}$ hygromycin. Hygromycin dose was increased by $5 \mathrm{ppm}$ in every subculture period (one month for each subculture up to $25 \mathrm{ppm}$ ). Survived calli and growth rates were observed 4 months after electroporation. Untreated calli were cultured in EE medium without hygromycin and used as control.

\section{Transient GUS gene expression assay}

Samples of electroporated calli were collected 3 days after electroporation. Non-electroporated calli and electroporated calli without plasmid were used as control. For each assay, 5 calli clumps were submerged in $0.5 \mathrm{~mL}$ phosphate buffer that contained 50 ppm X-gluc (5-bromo4-chloro-3-indolyl glucuronide, Thermo Fisher Scientific, USA). Incubation was carried out at $28^{\circ} \mathrm{C}$ without light for 16 hours. Samples were dried in filter paper and observed using stereomicroscope.

\section{Molecular analysis of survived calli}

Survived calli under 25 ppm hygromycin selection were selected and treated with DNase I (NEB, cat. no. M0303S) before DNA isolation to eliminate residual plasmid from calli. Direct DNA isolation without Dnase I treatments was also performed. Nested Polymerase Chain Reactions (PCRs) were used for specific molecular identification. List of used primers and related information is shown in Table 1. The primers were manually designed by taking into account the GC content of each primer. Nested PCR was carried out by two steps PCR, first-round PCR products with HPT primers were used as templates for second round PCR with HPTnest primers. OP primers were used for oil palm genome confirmation while HPT and HPTnest primer were used for target gene identification. The following PCR condition was used: $5 \mathrm{~min}$ pre-denaturation at $95^{\circ} \mathrm{C}$, 35 cycles of $30 \mathrm{~s}$ denaturation at $95^{\circ} \mathrm{C} ; 30 \mathrm{~s}$ annealing at $55^{\circ} \mathrm{C} ; 1 \mathrm{~min}$ extension at $72^{\circ} \mathrm{C}$, and $10 \mathrm{~min}$ final extension at $72^{\circ} \mathrm{C}$. The PCR products were separated by $1 \%$ gel agarose electrophoresis followed by staining with ethidium bromide dye and visualized under UV transilluminator. Specific bands related to target gene were purified and sequenced.

\section{Statistical analysis}

All the experiments were carried out using completely randomized design. Hygromycin lethal dose trials were performed in triplicate with 10 calli for each replicate and the data was used for regression analysis. Electroporation trials were performed in triplicate with 20 calli for each replicate and results were shown as mean \pm standard deviation. A one-way analysis of variance (ANOVA) and Duncan's multiple range tests (DMRT) was used to establish the significance $(\mathrm{P}<0.05)$ of differences. Arcsine transformation was performed for survival rates data before ANOVA and DMRT to fit normal distribution. All results were analyzed using the SPSS version 20 software program (IBM, USA). 
Table 1. Primers for molecular analysis

\begin{tabular}{lllc}
\hline \multicolumn{1}{c}{ Primer } & \multicolumn{1}{c}{ Sequence } & \multicolumn{1}{c}{ Target site } & Product size (bp) \\
\hline OP-F & CGAAATGGACTGCTGAAGATA & Oil palm MADS-box gene & 550 \\
OP-R & AAGCAAATAAATTGAAGAGGAGC & & \\
& & & 804 \\
HPT-F & CCTGAACTCACCGCGACG & hptII gene in pCAMBIA 1303 & plasmid \\
HPT-R & AAGACCAATGCGGAGCATATA & & 468 \\
HPTnest-F & GATGTTGGCGACCTCGTATT & & \\
HPTnest-R & GTGCTTGACATTGGGGAGTT & & \\
\hline
\end{tabular}

\section{RESULTS AND DISCUSSION}

\section{Hygromycin lethal dose analysis}

Hygromycin lethal dose towards oil palm calli was observed to obtain optimal concentration for selection of transformed calli. Regression analysis was performed for the data observed after 8 weeks incubation period (Figure 1). Most of calli (90\%) failed to survive in medium containing $35 \mathrm{ppm}$ hygromycin. Regression equation for hygromycin lethal doses was $y=-2.5+0.33 x+0.07 x^{2}$, where $y$ was the percentage of death calli and $\mathrm{x}$ was the hygromycin dose. Hygromycin lethal dose (LD100) for oil palm calli using regression equation was $36.8 \mathrm{ppm}$.

\section{Transient GUS gene expression}

Electroporated calli were subjected to GUS assay for detection of transient gene expression. Unexpected results were observed in electroporated callus after GUS assay where blue color was detected in all treated samples including fresh callus (Figure 2). Due to this result, DNA delivery to callus by electroporation could not be confirmed at this initial stage.

\section{Electric field strength optimization}

Visual observation was carried out to determine the explants condition 4 months after electroporation. Calli electroporated with electric field strengths of 250-1,000 $\mathrm{V} / \mathrm{cm}$ were able to proliferate under hygromycin selection (Figure 3). On the other hand, no significant calli growth was found in $1,250 \mathrm{~V} / \mathrm{cm}$ electroporation treatment. It was observed that variation of callus growth was quite high.

Growth rates and number of survived calli were observed in the same period of visual observation (Table 2 ). Highest growth rates of electroporated calli were obtained from electric field strength of $250 \mathrm{~V} / \mathrm{cm}$ treatment. Calli growth rates were decreasing in higher electric field strength except for the growth rates between 500 and $750 \mathrm{~V} / \mathrm{cm}$ treatment. Statistical analysis showed that growth rates of $250 \mathrm{~V} / \mathrm{cm}$ electroporation were significantly different $(\mathrm{P}<0.05$, ANOVA one way-test) towards other treatments except for $750 \mathrm{~V} / \mathrm{cm}$ electroporation while no significant difference was observed between 500-1,250 V/cm electroporation treatment. Data of survived calli from 250-1,000 V/cm electroporation treatments were not significantly different due to high variance in observed data. Data of survived calli from $1,250 \mathrm{~V} / \mathrm{cm}$ electroporation was significantly different from other treatments. It was difficult to determine optimum electric field strength from number of survived calli data because there were no significant differences in most of the treatments.

\section{Molecular analysis of survived calli}

Due to unexpected results in transient GUS expression assay, molecular analysis by PCR was performed to identify the transgene in survived calli. DNase was applied prior to DNA isolation to eliminate residual plasmid which may give a false-positive result in the analysis. DNA from calli which directly isolated without DNAse treatment was also used as control.

PCR result using direct isolated DNA and isolated DNA after DNAse treatment showed similar results (data not shown). This indicated that there were no residual plasmids in surviving calli 4 months after electroporation. Oil palm genomes were confirmed by PCR using OP primers. Amplified products with size slightly above 500 bp could be found in all electroporated calli treatments, calli submerged in plasmid-containing buffer without electroporation, and oil palm genome (Figure 4a). There were no products found in pCAMBIA 1303 plasmid and negative control $\left(\mathrm{ddH}_{2} \mathrm{O}\right)$. This result showed that DNA in electroporated calli samples were oil palm genome and PCR reactions could be performed with these samples.

Target gene was confirmed by using nested PCR with HPT and HPTnest primers (Figures 4.B and 4.C). For the first round PCR using HPT primers, amplified products with size around $750 \mathrm{bp}$ were only obtained in pCAMBIA 1303 plasmid template (Figure 4b). All PCR products from the first round PCR were used as templates for second PCR. For the second round PCR using HPTnest primers, amplified products were obtained in all electroporated calli and pCAMBIA 1303 plasmid (Figure 4c). No amplified products were detectable in calli submerged in plasmidcontaining buffer without electroporation, oil palm genome, and negative control $\left(\mathrm{ddH}_{2} \mathrm{O}\right)$. 
Table 2. Growth rates and number of survived calli 4 months after electroporation

\begin{tabular}{lrlrl}
\hline $\begin{array}{c}\text { Electric field } \\
\text { strength (V/cm) }\end{array}$ & $\begin{array}{c}\text { Growth rates } \\
\left(\mathbf{m m}^{\mathbf{2}}\right)^{*}\end{array}$ & $\begin{array}{c}\text { Survived calli } \\
(\boldsymbol{\%}) * / * *\end{array}$ \\
\hline 0 (Control) & $48.9 \pm 5$ & $\mathrm{a}$ & 100 & $\mathrm{a}$ \\
250 & $23.6 \pm 10.3$ & $\mathrm{~b}$ & $57 \pm 25$ & $\mathrm{a}$ \\
500 & $11.8 \pm 3$ & $\mathrm{c}$ & $67 \pm 36$ & $\mathrm{a}$ \\
750 & $14.9 \pm 4.4$ & $\mathrm{bc}$ & $75 \pm 13$ & $\mathrm{a}$ \\
1,000 & $12.0 \pm 2.2$ & $\mathrm{c}$ & $68 \pm 18$ & $\mathrm{a}$ \\
1,250 & $6.1 \pm 0.2$ & $\mathrm{c}$ & $18 \pm 2$ & $\mathrm{~b}$ \\
$\mathrm{CV}(\%)$ & 26.57 & & 17.25 & \\
\hline
\end{tabular}

*Values in a column followed by same letter were not significantly different in P-value of 0.05 (DMRT). **Arcsine data transformation was performed to fit normal distribution. Presented survival calluses data were actually mean. Presented coefficient of variation $(\mathrm{CV})$ was generated from transformed data

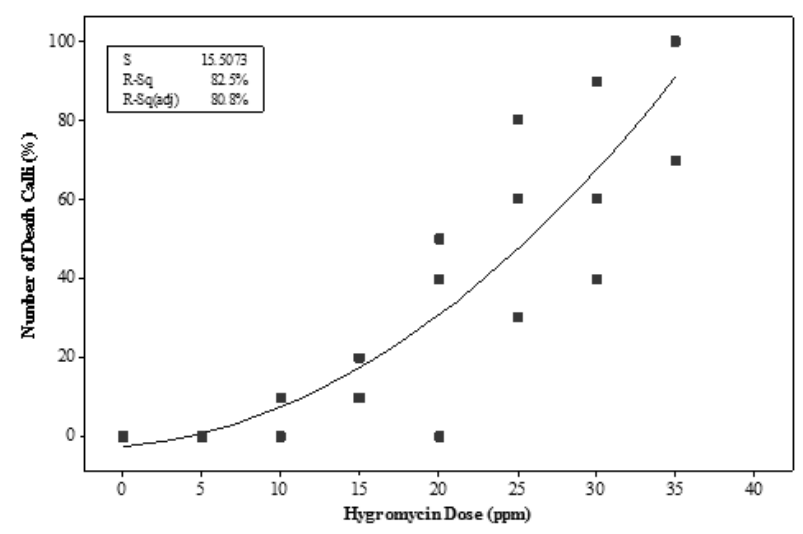

Figure 1. Regression analysis graph of hygromycin lethal doses after 8 weeks cultured

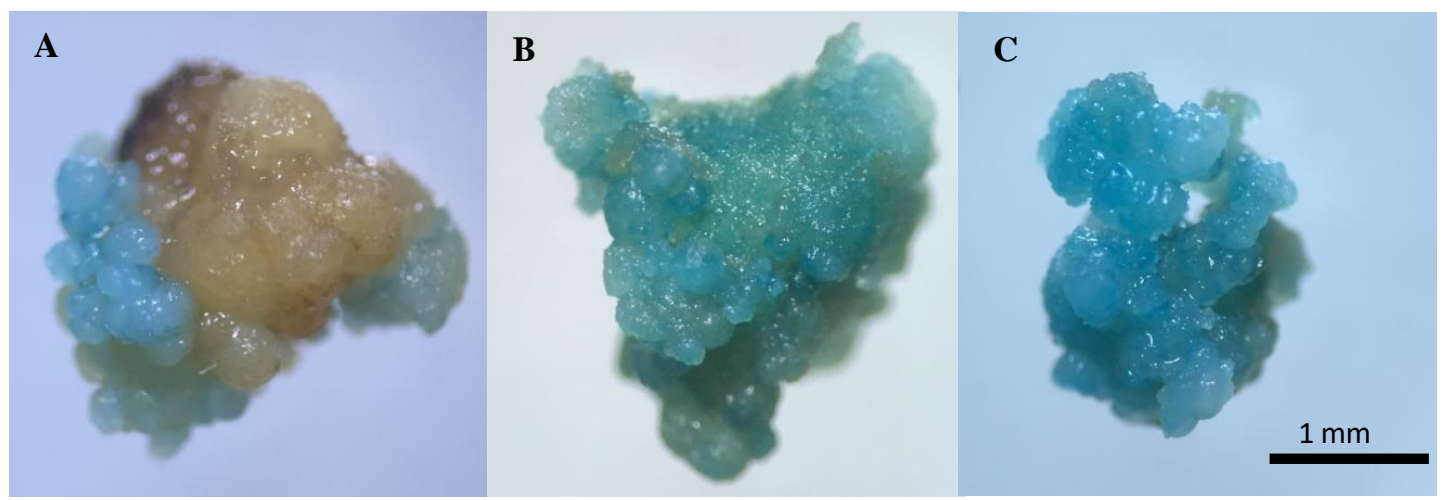

Figure 2. GUS assay of electroporated callus. A. Non-electroporated calli; B. Electroporated calli without plasmid; C. Electroporated calli with pCAMBIA 1303 plasmid

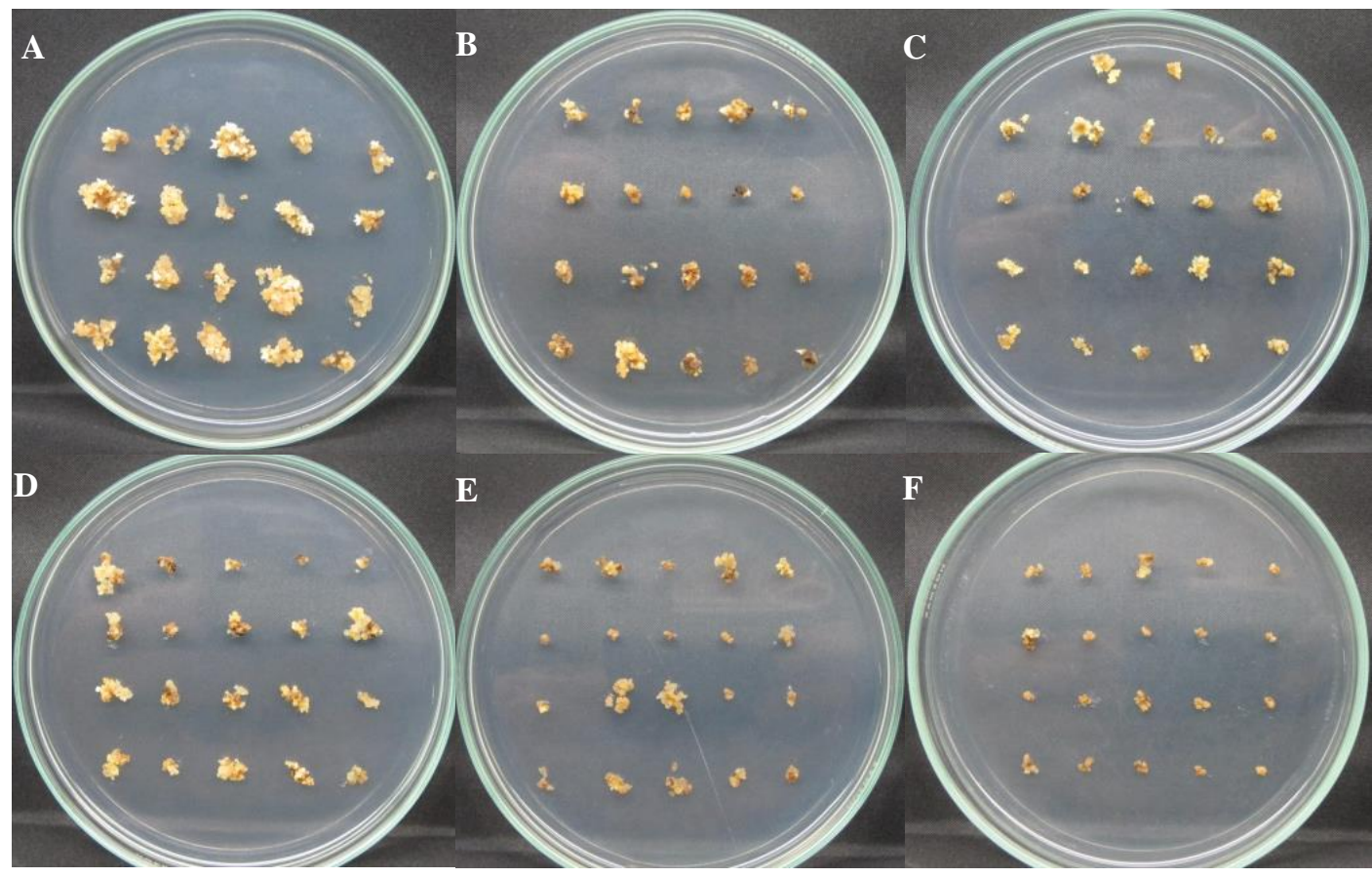

Figure 3. Visual appearance of electroporated calli 4 months after electroporation. A. Control calli in medium without hygromycin; Electroporated calli in medium contained 25 ppm hygromycin; B. $250 \mathrm{~V} / \mathrm{cm}$; C. $500 \mathrm{~V} / \mathrm{cm}$; D. $750 \mathrm{~V} / \mathrm{cm} ;$ E. 1,000 V/cm; f: 1,250 V/cm 


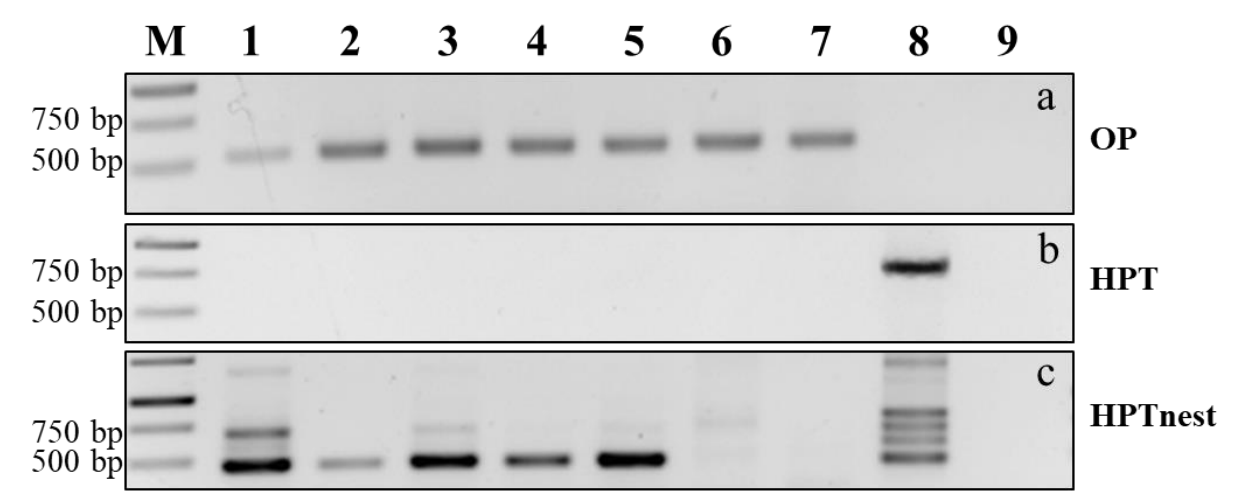

Figure 4. PCR analysis result using OP, HPT, and HPTnest primers. M: $1 \mathrm{~kb}$ DNA Ladder; DNA of electroporated calli with electric field strength of, 1. $250 \mathrm{~V} / \mathrm{cm}, 2.500 \mathrm{~V} / \mathrm{cm}, 3.750 \mathrm{~V} / \mathrm{cm}, 4.1,000 \mathrm{~V} / \mathrm{cm}, 5.1,250 \mathrm{~V} / \mathrm{cm}$; 6 . oil palm genome; 7. DNA of submerged calli in buffer contains plasmid without electroporation; 8. pCAMBIA 1303 plasmid; 9. $\mathrm{ddH}_{2} \mathrm{O}$

\section{Discussion}

Hygromycin is a selection antibiotic commonly used in oil palm transformation. Parveez et al. (1996) reported that $40 \mathrm{ppm}$ hygromycin and basta were optimal for selecting transformed oil palm embryogenic calli. It was necessary to evaluate lethal dose of selection agents before performing a genetic transformation because the lethal dose might be different for oil palm calli that were used in this research. Optimal hygromycin concentration would allow optimal selection of transformed calli. Hygromycin lethal dose in this research was slightly lower compared to the reference dose. In this research, we did not use lethal concentration for selection because we wanted to maintain cell viability. The maximum used concentration was $25 \mathrm{ppm}$ which allowed $50 \%$ oil palm calli to survive (LD50).

The successful process of DNA delivery using reporter gene usually can be detected through transient gene expression. $\beta$-glucuronidase (GUS) gene is widely used as a reporter gene in transformation of various plant species (Jefferson et al. 1987). Formation of blue spot in plant tissue, as a product of GUS activity towards X-gluc substrate, may indicate successful transformation procedure. The gene was also used for transient gene expression in various types of oil palm explant including somatic embryo (Mariani et al. 2015). It was reported that GUS expression was detected only in transformed explants while there was no blue color in control explants. On the contrary, GUS assay showed different results in our experiments where blue color was detected both in control and treated calli. We presumed from this result that oil palm plants might have endogenous GUS-like enzyme activities.

Several research found that the GUS or GUS-like gene expressions were natively present in some plant species. Sudan et al. (2006) observed the regulation of endogenous GUS expression in various tissues derived from model plants such as Arabidopsis thaliana, Oryza sativa, Nicotiana tabacum, and Zea mays. Similar expressions were also found in Capsicum chinense Jacq. (Solís-Ramos et al. 2010) and Brassica napus (Abdollahi et al. 2011). In these studies, the endogenous GUS expressions could be inhibited by adjusting the $\mathrm{pH}$ of assay buffer, methanol addition, or increasing assay temperatures thus allowing more precise observation of reporter gene expression. These findings show that there is a possibility of GUS-like gene in oil palm genome that can interfere with the GUS assay. Further research is needed to find more information related to this finding.

Electroporation had significant impact on callus growth rates. Higher electric field strengths resulted in lower calli growth rates. Saunders et al. (1995) reported that electric field strength in electroporation had inverse correlation with plant cell viabilities. It was explained that pores on cell membranes could be induced if the pulse exceeds threshold field strength for a critical duration. The pores would not be induced if applied pulse is below this threshold and if the threshold field strength is greatly exceeded then the cell membrane would be irreversibly damaged, resulting in cell death. It was also reported that an increased voltage and pulse length had a significant effect in reducing protoplast viability from various species (Ochatt 2013). The case of cell death in our experiment was observed in $1,250 \mathrm{~V} / \mathrm{cm}$ electroporation where oil palm calli did not proliferate because the applied electric field strength was too high.

In the same research by Saunders et al. (1995), it was also explained that the quantity of molecules that could pass through inside the cell would increase in accordance with increasing electric field strengths until it reached saturation phase. Higher electric shock would result in bigger pores on the cells surface which leads to more uptake of extracellular molecules (Jeon et al. 2013). Although higher electric field strengths in electroporation would allow more DNA to pass through cell membranes, calli viabilities were also affected. If the damage from electroporation was too high, calli would not be able to survive. Optimal electroporation parameter should also consider the growth rates of the explants. Based on those considerations, the optimal electric field strength for oil palm calli electroporation was $250 \mathrm{~V} / \mathrm{cm}$ because the treatment gave the highest growth rates and the presence of transgene could be confirmed by molecular analysis. 
Although no specific products could be detected in the first round PCR, amplified fragments related to target gene were detectable from all electroporation treatments after a second-round PCR. This result showed that there were transformed oil palm calli but their proportion was still very small in electroporated calli populations. Amplified products of electroporated calli from the first PCR were actually present but the concentration was too low to be visualized. Gradual selection allowed untransformed calli to survive when cultivated at low hygromycin concentration. As hygromycin concentration was increased in every subculture, the proportion of transformed calli would increase because untransformed calli were not able to survive. This result also showed that plasmid DNA was located in sub-cellular organelles because it was unlikely that plasmid DNA remained in cytoplasm for a long period of time since extrachromosomal genetic material in eukaryotic cell would be eliminated by cytosolic nuclease (Shimizu et al. 2005). All amplified products from electroporated calli were purified and further analyzed by sequencing. Sequencing results (data not shown) showed that PCR products were part of hygromycin transferase gene from pCAMBIA 1303 plasmid.

Electroporation-mediated plant genetic transformation has been applied in various plant species (Ozyigit 2020). It is usually carried out by using protoplasts because there are no cell walls that could inhibit DNA delivery. However, regeneration of transformants from protoplast is a major challenge since protoplast-to-plant regeneration system is not available for most plant species (Barampuram and Zhang 2011). By applying electroporation directly to plant tissue, it was expected that the problems with protoplasts would not affect plant regeneration. Sorokin et al. (2000) stated that tissue electroporation offers several potential advantages over microprojectile bombardment and Agrobacterium-mediated transformation, including: high viability of cells after electroporation, higher DNA delivery rate, applicability to single cells and cell clusters, equivalent conditions of treated explants, technical simplicity, and low cost.

In this research, a range of electric field strengths has been tested for delivering specific genes into the oil palm cell using electroporation. Molecular analysis confirmed that the transgenes could be detected in samples from all electroporation treatment. All tested electric field strengths were able to deliver the gene into oil palm cells and 250 $\mathrm{V} / \mathrm{cm}$ treatment, which generated higher explant growth rates, was recommended for oil palm calli transformation. Although mature transgenic oil palm plant was not yet regenerated in this research, transformed oil palm calli were successfully confirmed.

Another prospective approach is to use oil palm liquid culture as explant for electroporation as demonstrated in algae genetic transformation. In related studies, this technique has been successfully used to deliver genes of interest into Chlamydomonas reinhardtii (Qu et al. 2012), Neochloris oleoabundans (Chungjatupornchai et al. 2016), and Phaeodactylum tricornutum (Niu et al. 2012). Although plant and algae cells behave differently during their development, the reports showed that cell wall barriers can be penetrated as long as the electroporation conditions are optimized. In addition, Furuhata et al. (2019) performed electroporation-mediated protein delivery into cultured Arabidopsis cells. The Cre recombinase was successfully transferred through the cell wall with high efficiency. Liquid culture is technically easier to handle and large amount of single cells can be electroporated at the same time. This interesting approach may be elaborated on future research. Overall, the successful event of gene delivery showed that electroporation can be potentially used as transformation technique for oil palm and further improvement related to the methods is needed.

\section{ACKNOWLEDGEMENTS}

This project was fully funded by PT SMART Tbk. The authors would like to express their great appreciation to the director of Plant Production and Biotechnology Division for permission to publish this article.

\section{REFERENCES}

Abdollahi MR, Memari HR, van Wijnen AJ. 2011. Factor affecting the endogenous $\beta$-glucuronidase activity in rapeseed haploid cells: How to avoid interference with the Gus transgene in transformation studies. Gene 487 (1): 96-102. DOI: 10.1016/j.gene.2011.07.007

Brew-Appiah RA, Ankrah N, Liu W, Konzak CF, von Wettstein D, Rustgi S. 2013. Generation of doubled haploid transgenic wheat lines by microspore transformation. PloS one 8 (11): e80155. DOI: 10.1371/journal.pone.0080155

Barampuram S, Zhang ZJ. 2011. Recent Advances in Plant Transformation. In: Birchler J (eds) Plant Chromosome Engineering. Methods in Molecular Biology (Methods and Protocols). Humana Press, Totowa, NJ.

Chungjatupornchai W, Kitraksa P, Fa-aroonsawat S. 2016. Stable nuclear transformation of the oleaginous microalga Neochloris oleoabundans by electroporation. J Appl Phycol 28: 191-199. DOI: 10.1007/s10811015-0594-5

D'Halluin K, Bonne E, Bossut M, De Beuckeleer M, Leemans L. 1992. Transgenic maize plants by tissue electroporation. Plant Cell 4 (12): 1495-1505. DOI: 10.1105/tpc.4.12.1495

Furuhata Y, Sakai A, Murakami T, Morikawa M, Nakamura C, Yoshizumi T, Fujikura U, Nishida K, Kato Y. 2019. A method using electroporation for the protein delivery of Cre recombinase into cultured Arabidopsis cells with an intact cell wall. Sci Rep 9: 2163. DOI: $10.1038 / \mathrm{s} 41598-018-38119-9$

Izawati AMD, Parveez GKA, Masani MYA. 2012. Transformation of Oil Palm Using Agrobacterium tumefaciens. In: Dunwell JM, Wetten AC (eds) Transgenic Plants. Humana Press, Totowa, NJ.

Jefferson RA, Kavanagh TA, Bevan MW. 1987. GUS fusions: beta-glucuronidase as a sensitive and versatile gene fusion marker in higher plants. EMBO J 6 (13): 3901-3907.

Jeon K, Suresh A, Kim YC. 2013. Highly efficient molecular delivery into Chlamydomonas reinhardtii by electroporation. Korean J Chem Eng 30 (8): 1626-1630. DOI: 10.1007/s11814-013-0098-4

Kumar P, Nagarajan A, Uchil PD. 2019. Electroporation. Cold Spring Harb Protoc (7): pdb-top096271.

Liu XZ, Li HL, Lou RH, Zhang YJ, Zhang HY. 2010. Transgenic Pinus armandii plants containing BT obtained via electroporation of seedderived embryos. Sci Res Essays 5 (22): 3443-3446.

Mariani TS, Ermavitalini D, Mitsutaka T, Chia TF, Miyake H. 2015. GUS gene expression in somatic embryo of oil palm (Elaeis guineensis Jacq.). Asian J Appl Sci 3(5): 649-650.

Masani MYA, Noll GA, Parveez GKA, Sambanthamurthi R, Prüfer D. 2014. Efficient transformation of oil palm protoplasts by PEGmediated transfection and DNA microinjection. PloS one 9 (5): e96831. DOI: 10.1371/journal.pone.0096831 
Masani MYA, Izawati AMD, Rasid OA, Parveez GKA. 2018 Biotechnology of oil palm: Current status of oil palm genetic transformation. Biocatal Agric Biotechnol 15: 335-347. DOI: 10.1016/j.bcab.2018.07.008.

Niu YF, Yang ZK, Zhang MH, Zhu CC, Yang WD, Liu JS, Li HY. 2012 Transformation of diatom Phaeodactylum tricornutum by electroporation and establishment of inducible selection marker. Biotechniques 52 (6). DOI: 10.2144/000113881.

Ochatt S. 2013. Plant cell electrophysiology: Applications in growth enhancement, somatic hybridisation, and gene transfer. Biotechnol Adv 31 (8): 1237-1246. DOI: 10.1016/j.biotechadv.2013.03.008.

Ozyigit II. 2020. Gene transfer to plants by electroporation: methods and applications. Mol Biol Rep 47 (4): 3195-3210. DOI: 10.1007/s11033020-05343-4.

Parveez GKA, Bahariah B, Ayub NH, Masani MYA, Rasid OA, Tarmizi AH, Ishak Z. 2015. Production of polyhydroxybutyrate in oil palm (Elaeis guineensis Jacq.) mediated by microprojectile bombardment of PHB biosynthesis genes into embryogenic calli. Front Plant Sci 11 (6): 598. DOI: 10.3389/fpls.2015.00598.

Parveez GKA, Chowdhury MKU, Saleh M. 1996. Determination of minimal inhibitory concentration of selection agents for oil palm (Elaeis guineensis Jacq.) transformation. Asia Pac J Mol Biol Biotechnol 4: 219-228.

Parveez GKA, Rasid OA, Hashim AT, Ishak Z, Rosli SK, Sambanthamurthi R. 2012. Tissue culture and genetic engineering of oil palm. In: Lai OM, Tan CP, Akoh CC (eds). Palm Oil. AOCS Press, Urbana, IL.
Qu B, Eu YJ, Jeong WJ, Kim DP. 2012. Droplet electroporation in microfluidics for efficient cell transformation with or without cell wall removal. Lab Chip 12 (21): 4483-4488.

Reberšek M. 2017. Beyond Electroporation Pulse Parameters: From Application to Evaluation. In: Miklavcic D (eds). Handbook of Electroporation. Springer, Cham.

Rivera AL, Gómez-Lim M, Fernández F, Loske AM. 2012. Physical methods for genetic plant transformation. Phys Life Rev 9 (3): 30845. DOI: 10.1016/j.plrev.2012.06.002.

Saunders JA, Lin CH, Hou BH, Cheng J, Tsengwa N, Lin JJ, Smith CR, McIntosh MS, Van Wert S. 1995. Rapid optimization of electroporation conditions for plant cells, protoplasts, and pollen. Mol Biotechnol 3 (3): 181-190.

Shimizu N, Kamezaki F, Shigematsu S. 2005. Tracking of microinjected DNA in live cells reveals the intracellular behavior and elimination of extrachromosomal genetic material. Nucleic Acids Res 33 (19): 62966307. DOI: 10.1093/nar/gki946

Solís-Ramos LY, González-Estrada T, Andrade-Torres A, GodoyHernández G, Castaño de la Serna E. 2010. Endogenous GUS-like activity in Capsicum chinense Jacq. Electron J Biotechnol 13 (4): 2-3. DOI: 10.2225/vol13-issue4-fulltext-3

Sorokin AP, Ke XY, Chen DF, Elliott MC. 2000. Production of fertile transgenic wheat plants via tissue electroporation. Plant Sci 156 (2): 227-233. DOI: 10.1016/s0168-9452(00)00260-0

Sudan C, Prakash S, Bhomkar P, Jain S, Bhalla-Sarin N. 2006. Ubiquitous presence of $\beta$-glucuronidase (GUS) in plants and its regulation in some model plants. Planta 224 (4): 853-864. DOI: 10.1007/s00425006-0276-2. 